\title{
Analysis of the applicability of a common rail pump for an aircraft engine
}

The paper presents an analysis of the possibility of using a common rail pump to supply an aircraft compression-ignition engine. It is an engine with a two-stroke cycle, three cylinders, opposing pistons and $100 \mathrm{~kW}$ power. Its each combustion chamber is supply by one or two injectors controlled by electromagnetic valves. In order to assess the possibility of using a common rail pump, four high-pressure pumps were tested on a bench. They are piston pumps differing in the number and geometry of their pumping sections. The analysis included the pumping output, the torque on the pump drive shaft and the power needed to drive the pump. The weight and overall dimensions of the pump were also considered, including the arrangement of the pumping sections and the way the drive is transmitted. The research allowed to optimize the engine power supply system depending on fuel demand and the way the pump is mounted on the engine.

Key words: diesel engine, two-stroke, opposing piston, fuel pump, common rail

\section{Introduction}

Demanding requirements to reduce exhaust emissions and fuel consumption are increasingly affecting internal combustion engines for non-motorization applications. At the same time, the aim is to increase the power factor. As a result, intensive research work is underway to develop a diesel-powered engine for the propulsion of aircraft. Due to a number of advantages, such as: lack of the head (less heat loss) and the camshaft system, opposing piston movement conducive to engine balancing, the piston opposed diesel engine operating in a two-stroke cycle was developed and modernized [1-3]. Obviously, such a construction also has drawbacks. The main one is the need to use a gear that connects two crankshafts or a complex crank system with one shaft. The development of these engines so far has been limited by regulations on meeting the emission standards for particulate matter and hydrocarbons [4]. With the development of electronics and materials engineering, these engines are now experiencing a renaissance. The optimistic research results $[5-7,24]$ intensified the work on the development of efficient two-stroke diesel engines [8, 9, 25]. One of the ways to eliminate unfavorable exhaust emissions while reducing fuel consumption is to use one of the most modern fuel supply systems. The development in this field has allowed the development of a high-pressure, common rail diesel fuel supply system for diesel engines which is widely used in the automotive industry. Compared to previous solutions, it is more flexible in terms of injection, high fuel pressure generation and control and reduced energy demand [10-12].

The literature reports on some research into the injection process and related fuel dynamics [13-15, 23], a maintenance of a given fuel pressure in the tank [16-18] or an injection control strategy [19-21].

An equally important part of the fuel system is the highpressure pump. In the case of aircraft engines, no new pumps are built, but the proven solutions available on the automotive market are used. The market offer are high pressure pumps, manufactured mainly by Bosch, Denso, Delphi, Siemens. Applying this solution in aviation, the safety aspects of aircraft maintenance and operation need to be remembered. On the one hand, the smallest and lightest components must be used, but on the other hand, it must ensure safe and reliable operation of the engine. This gives rise to the dilemma of which pump to choose: singlesection, small, light and adjusted to the demand, or a large and heavy multi-sectional pump with oversized efficiency. The required pumping output will, of course, depend on the configuration of the fuel system, namely the type and number of injectors.

The paper presents the results of the tests of high pressure pumps for a two-stroke compression-ignition engine with opposing pistons. The engine has three cylinders, power about $100 \mathrm{~kW}$ at shaft speed of $3800 \mathrm{rpm}$. Its each combustion chamber be supply by one or two injectors controlled by solenoid valves. The research allowed us to optimize the fuel supply system in terms of both efficiency and weight as well as the manner it is installed on the engine and power is transmitted.

\section{Experimental apparatus and procedure}

\subsection{Test bench}

The research was carried out on a test stand for testing common rail system elements. This is the STPiW3 test stand (Fig. 1) which is equipped with additional control and

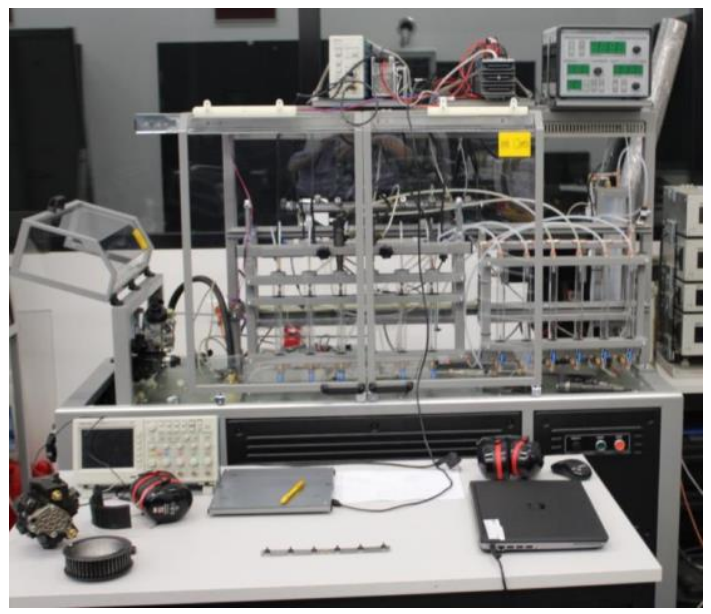

Fig. 1. Common rail system component test bench 
measurement systems. Such a test bench enables tests of injectors, high pressure pumps, dosing valves, fuel pressure control valves and pressure sensors. Universal mounting holders allow you to test varied pumps and injectors. High pressure pump is driven with a three-phase $4 \mathrm{~kW}$ electric motor controlled by an inverter. The temperature stabilization system enables long-term measurements in constant thermal conditions of the fuel. The diagram of the measuring system is shown in Fig. 2.

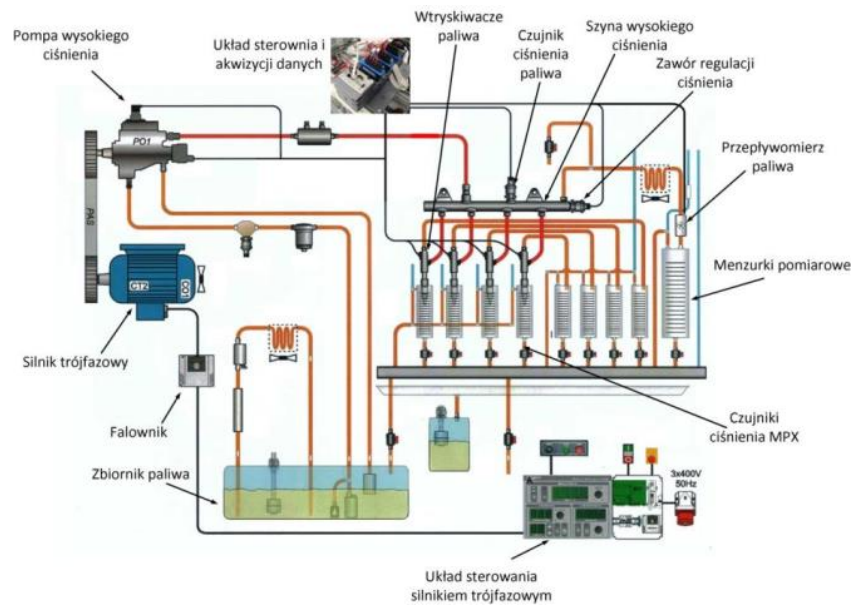

Fig. 2. Diagram of the test bench for testing Common Rail system components [28]

In order to determine the characteristics of highpressure pumps, the test stand was equipped with control and measurement systems. Control of the common rail system was performed using National Instruments data acquisition cards and the LabView software. This special control and measurement system includes:

- control of actuators:

- fuel dispenser in the high-pressure pump,

- fuel pressure regulator in the fuel rail,

- measurements:

- pump flow rate,

- fuel pressure in the rail,

- torque on the pump shaft,

- pump shaft speed,

- recording and data acquisition system.

To control the actuators, NI-9758 card is used. It allows to control PWM (0-100\%) up to four solenoid valves at a maximum current load of $1.5 \mathrm{~A}$ (continuous operation), a frequency operation of $2 \mathrm{~Hz}-10 \mathrm{kHz}$, a resolution of 500 ns, short-circuit and open circuit detection, supplied from an external source with a voltage of 7-32 V [26].

The control system is based on the CompactRIO-9024 controller. It is a real-time control and data logging device based on a $800 \mathrm{MHz}$ clocked CPU for use in research systems. The platform has a built-in network interface with a data transfer rate of up to $1000 \mathrm{Mbps}$ which enables remote communication and a retrieval of data logged by the device. It has a built-in 4 GB memory and 512 MB DRAM [26].

High pressure pumps are tested with a special program developed in the National Instruments LabView software. Due to hardware requirements, the program had to consist of two modules. The first one was responsible for synchro- nizing and communicating the actuator cards with the real time controller using DMA channels. The second module, FPGA Xilinx Virtex-5 LX110, is built in a chassis cRIO9118. It has programmable logic blocks called CLB, I/O type blocks and programmable internal links. The possibilities of programming a particular block and the connections between the blocks are stored in the internal RAM memory.

The voltage measurement signals were recorded with the NI 9205 card. It is a sixteen-channel measuring card with a resolution of 16 bits and a maximum sampling rate of $250 \mathrm{kS} / \mathrm{s}$. The signal level is $\pm 10 \mathrm{VDC}$ and the absolute accuracy for the range is $\pm 10 \mathrm{VDC}$ at a full scale of 6.230 $\mu \mathrm{V}[26]$.

High-pressure pumps were measured with rotor fuel flow meters: DHGF-2 (Fig. 3) and DHGF-4 depending on maximum pump flow rate. Basic technical data of the flow meters is presented in Table 1.

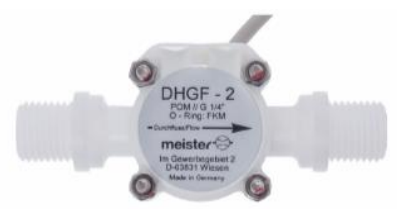

Fig. 3. Flow meter DHGF-2 from Meister [29]

Table 1. Technical data of DHGF series flow meters [29]

\begin{tabular}{|l|c|c|}
\hline Parameter & Unit & Value \\
\hline Operating pressure, max. & $\mathrm{MPa}$ & 1.0 \\
\hline Burst pressure $\left(22^{\circ} \mathrm{C}\right)$ & $\mathrm{MPa}$ & $>3.0$ \\
\hline Operating temperature & ${ }^{\circ} \mathrm{C}$ & $0-80$ \\
\hline Measuring accuracy & $\%$ & \pm 2 of the measured value \\
\hline Repeatability & $\%$ & $< \pm 0.8$ of the measured value \\
\hline Viscosity range & $\mathrm{cSt}$ & $1-10$ \\
\hline Sensing principle & & $\begin{array}{c}\text { Hall effect, contact-free } \\
\text { measuring technique }\end{array}$ \\
\hline Process connection & $"$ & Threaded G $1 / 4$ or $5 / 8$ UNF \\
\hline Power supply & $\mathrm{VDC}^{4}$ & $4.5-24$ \\
\hline Output signal & & $\begin{array}{c}\text { Square wave push-pull } \\
\text { output stage }\end{array}$ \\
\hline Max. output current (at $24 \mathrm{~V})$ & $\mathrm{mA}$ & 11 \\
\hline Measuring range & \multicolumn{2}{|c|}{$1.5-100$} \\
\hline DHGF-2 & $\mathrm{dm}^{3} / \mathrm{h}$ & $6-250$ \\
\hline DHGF-4 & $\mathrm{dm}^{3} / \mathrm{h}$ & \multicolumn{2}{|c|}{} \\
\hline
\end{tabular}

To determine the power required to drive the pump, a measuring system was built. Accordingly, the STPiW3 test stand was modernized and equipped with a torque and pump shaft speed measurement system (Fig. 4). The tested pump is mounted on a mounting plate mounted on a frame. The frame and the bearing housings are pin-connected. The axis of rotation of the frame is collinear with the axis of rotation of the pump drive shaft, which enables the transfer of torque from the pump casing to the frame through the plate. This is a universal measuring system capable of testing different pump designs. The pendulum-mounted frame is connected to the station structure by means of a ZEMIC H3-C3-75 kg strain gauge. Torque was measured by measuring the force acting on the spot where the strain gauge is mounted, located $100 \mathrm{~mm}$ from the axis of rotation and perpendicularly to the axis of rotation of the pump shaft. Basic technical data of the strain gauge is presented in Table 2. 

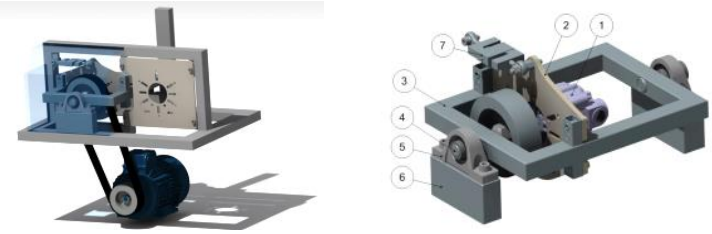

Fig. 4. Torque measuring system on the high-pressure pump shaft: 1 - high pressure pump, 2 - mounting plate, 3 - frame, 4 - frame pins, 5 - bearing housing, 6-distance column, 7 - load cells sensor

Table 2. Technical parameters of ZEMIC load cells sensor H3-C3-75 kg [27]

\begin{tabular}{|l|c|c|}
\hline \multicolumn{1}{|c|}{ Parameter } & Unit & Value \\
\hline Sensor type & & tensometric sensor S-type \\
\hline Measuring range & $\mathrm{kg}$ & $\leq 75$ \\
\hline Combined error & $\% \mathrm{FS}$ & $\leq \pm 0.020$ \\
\hline Power supply & $\mathrm{VDC}$ & $5 \ldots 12$ \\
\hline Output signal & $\mathrm{mV}$ & $0 \ldots 20$ \\
\hline Terminal resistance, input & $\Omega$ & $351 \pm 2.0$ \\
\hline Temperature range, operating & ${ }^{\circ} \mathrm{C}$ & $-35 \ldots+65$ \\
\hline
\end{tabular}

\subsection{Scope of the tests} tions:

The tests were carried out under the following condi-

- temperature of the calibration fluid $-40^{\circ} \mathrm{C}$,

- preliminary pump supply pressure $-0.4 \mathrm{MPa}$,

- high-pressure pump shaft speed - 500-2500 rpm,

- pumping pressure (in the rail) - 0-140 MPa.

The preset pressure was maintained by means of a solenoid valve and was the result of the PID controller. During the tests, each measurement point was defined by pump's shaft rotation speed and the pressure in the rail. The values of pump volumetric flow rate and average torque on the camshaft were recorded four times in 10-second intervals. Additionally, torque, fuel pressure and pump shaft speed with a frequency of $2 \mathrm{kHz}$ were recorded. The average torque value enabled us to specify the power required to drive the pump and then the specific energy demand to obtain the given value of flow rate.

\subsection{Subject of the research}

The pumps used in the research are widely applied Bosch pumps of different generations and the Denso pump:

1. Bosch CP1_H3,

2. Bosch CP4_1,

3. Bosch CP4_2,

4. Denso HP3.

These are one, two and three section positive displacement pumps with a single or double cam roller. In CP1, the sections are arranged in the body on its circumference every $120^{\circ}$, in CP4.2, they are shifted to each other by $90^{\circ}$ and in HP3 by $180^{\circ}$. Compared to the previous solutions (CP1), the $\mathrm{CP} 4$ series has an optimized design by reducing the number of components and using an aluminum pump casing. High fuel pressure is generated in the pumping section and then forwarded directly through high pressure lines to the rail. There are no channels in the body for high-pressure fuel flow as it is in the CP1 pump. The same is true for HP3, where the pumping sections are connected by an external steel pipe. The pump body is made of aluminum alloys. Unlike CP pumps, the HP3 pump has a trochoid type pre-pump. The basic technical data of the tested pumps is presented in Table 3.

Table 3. Technical parameters of high-pressure pumps

\begin{tabular}{|l|c|c|c|c|c|}
\hline $\begin{array}{c}\text { Pump } \\
\text { name }\end{array}$ & $\begin{array}{c}\text { No. of } \\
\text { pumping } \\
\text { sections }\end{array}$ & $\begin{array}{c}\text { Max } \\
\text { piston } \\
\text { stroke }\end{array}$ & $\begin{array}{c}\text { Piston } \\
\text { diame- } \\
\text { ter }\end{array}$ & $\begin{array}{c}\text { No. of pump- } \\
\text { ing per rota- } \\
\text { tion }\end{array}$ & $\begin{array}{c}\text { Theoretical } \\
\text { flow rate }\end{array}$ \\
\hline $\begin{array}{l}\text { Bosch } \\
\text { CP1_H3 }\end{array}$ & 3 & 5.77 & 7 & 3 & 665.83 \\
\hline $\begin{array}{l}\text { Bosch } \\
\text { CP4_1 }\end{array}$ & 1 & 7.43 & 5.5 & 2 & 352.87 \\
\hline $\begin{array}{l}\text { Bosch } \\
\text { CP4_2 }\end{array}$ & 2 & 6.00 & 6.5 & 4 & 795.99 \\
\hline $\begin{array}{l}\text { Denso } \\
\text { HP3 }\end{array}$ & 2 & 9.00 & 8.5 & 2 & 1020.89 \\
\hline
\end{tabular}

\begin{tabular}{|l|c|c|c|c|}
\hline $\begin{array}{c}\text { Pump } \\
\text { name }\end{array}$ & drive system & mount & Pre-pump & mass \\
\hline $\begin{array}{l}\text { Bosch } \\
\text { CP1_H3 }\end{array}$ & $\begin{array}{c}\text { belt } \\
\text { transmission }\end{array}$ & flange & ext. elec. & 4.80 \\
\hline $\begin{array}{l}\text { Bosch } \\
\text { CP4_1 }\end{array}$ & $\begin{array}{c}\text { belt } \\
\text { transmission }\end{array}$ & flange & ext. elec. & 2.65 \\
\hline $\begin{array}{l}\text { Bosch } \\
\text { CP4_2 }\end{array}$ & $\begin{array}{c}\text { belt } \\
\text { transmission }\end{array}$ & flange & ext. elec. & 3.80 \\
\hline $\begin{array}{l}\text { Denso } \\
\text { HP3 }\end{array}$ & $\begin{array}{c}\text { belt } \\
\text { transmission }\end{array}$ & flange & int. trochoid type & 3.90 \\
\hline
\end{tabular}

All pumps are equipped with a dosing valve that allows the pump output to be controlled independently of shaft speed. The valve is in the pump casing. The pumps have a flanged mounting and a possibility to place a gear wheel on the pump shaft. This enables us to install the pump in the engine block and drive it by a gear or belt drive.

\section{Results and discussion}

Table 4 summarizes the required volumetric flow rates of a high-pressure pump. The calculations were made for the engine operation at idle and maximum load conditions and for the option of supplying with three and six injectors (one or two per combustion chamber). The required volumetric flow rate includes injection volume, fuel from leaks and the process of injector control and $25 \%$ of the maximum fuel consumption.

Table 4. Required high-pressure pump volumetric flow rates

\begin{tabular}{|c|c|c|c|c|}
\hline Type of operation & $\begin{array}{l}\text { Injection } \\
\text { pressure }\end{array}$ & $\begin{array}{l}\text { Nolumetric of injectors } \\
\text { flow rate }\end{array}$ & 3 & 6 \\
\hline idle & $30 \mathrm{MPa}$ & \multirow{2}{*}{$\mathrm{dm}^{3} / \mathrm{h}$} & 3.45 & 5.98 \\
\hline max. load & $140 \mathrm{MPa}$ & & 54.37 & 76.32 \\
\hline
\end{tabular}

Figure 5 presents the analysis of the required volumetric flow rate with the volumetric flow rate of the tested pumps. The horizontal blue lines (idle) and red lines (max. load) illustrate the required flow rate demanded from by a high pressure pump. When the engine is supplied by three injectors, each of the tested pumps has the required volumetric flow rate, but if supplied by six injectors, the CP4.1 pump does not provide such a volumetric flow rate at maximum load. 


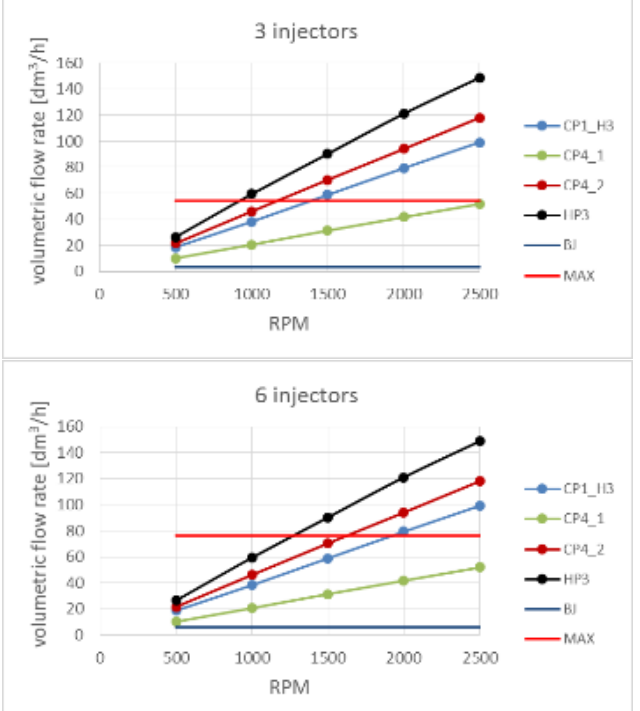

Fig. 5. Comparison of pump volumetric flow rates with the required pump volumetric flow rate - with three and six injectors

The HP3 pump consumes the most power (Fig. 6). At a pumping pressure of $30 \mathrm{MPa}$, it is from about $0.24 \mathrm{~kW}(500$ $\mathrm{rpm})$ to about $1.5 \mathrm{~kW}(2500 \mathrm{rpm})$. However, at a pumping pressure of $140 \mathrm{MPa}$, it is about 1.0 and $5.0 \mathrm{~kW}$, respectively. The lowest power is consumed by pump CP4.1, and then CP1_H3 and CP4.2. It is respectively about 35 and $76 \%$ of the power of pump HP3. The power demand increases linearly as the pump shaft speed increases. Obviously, the differences in the power demand to drive the pump are due to the different geometries of the pumping sections and associated the volumetric flow rates. Therefore, the further part of the paper analyzes the specific flow rates of the pumps.

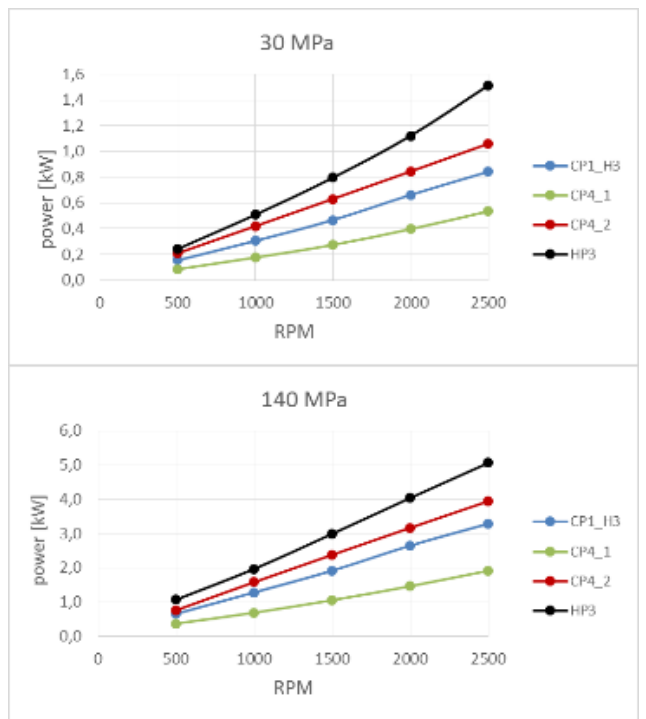

Fig. 1. Comparison of power to pump drive as a function of pump shaft speed for pumping pressures of 30 and $140 \mathrm{MPa}$

Figure 7 compares the specific pumping rate for pumps operating at a pumping pressure of $30 \mathrm{MPa}$ and $140 \mathrm{MPa}$. At a pumping pressure of $30 \mathrm{MPa}$, the largest specific flow rate of approx. $128 \mathrm{dm}^{3} / \mathrm{kWh}$ is registered for the CP1.H3 pump, followed by approx. $118 \mathrm{dm}^{3} / \mathrm{kWh}$ for the CP4.1 and HP3 pumps, and finally $112 \mathrm{dm}^{3} / \mathrm{kWh}$ for the CP4.2 pump. However, the CP4.2 pump keeps the specific flow rate at a similar level throughout the shaft speed range. The other pumps, on the other hand, achieve the maximum specific flow rate in the speed range of 500-1500 rpm, while with increasing speed, the flow rate decreases by about $20 \%$. With pumps operating at maximum pressure, a similar tendency to change the specific flow rate can be observed. However, maximum values of about $30 \mathrm{dm}^{3} / \mathrm{kWh}$ for $\mathrm{CP} 1$, CP4.1 and HP3 can be observed for 1000-1500 rpm. For higher and lower speeds, the flow rate decreases. For $\mathrm{CP} 4.2$, the maximum flow rate is reached at maximum speed. The difference between the max and min values is about $7 \%$ for CP1 and CP4.2 and about $15 \%$ for CP4.1 and HP3.

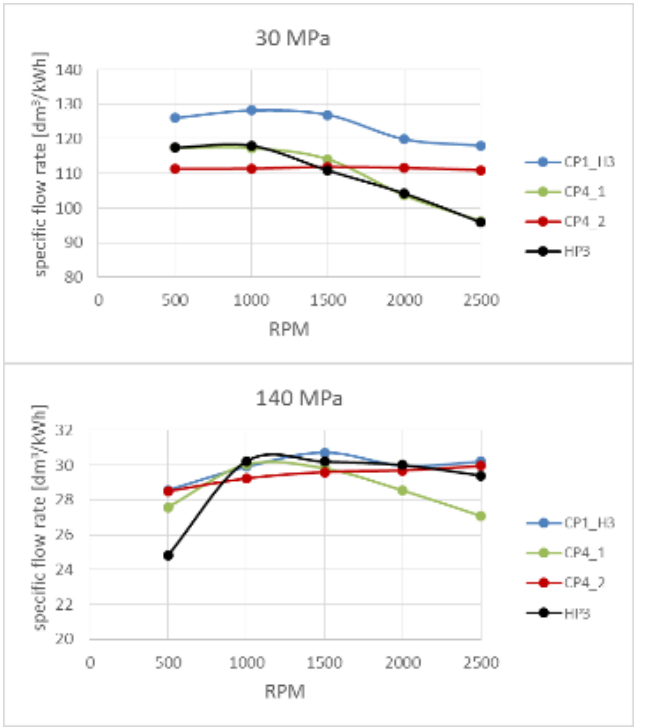

Fig. 2. Comparison of pump specific flow rates as a function of pump shaft speed for pumping pressures of 30 and $140 \mathrm{MPa}$

Figure 8 shows the torque on the shafts of the tested pumps. This is a sample for a pumping pressure of $30 \mathrm{MPa}$ and $2500 \mathrm{rpm}$. This figures enabled us to specify the values of the amplitude as well as the minimum and maximum torque on the pump shaft. The calculations were made for the pumping pressures of 30 and $140 \mathrm{MPa}$.

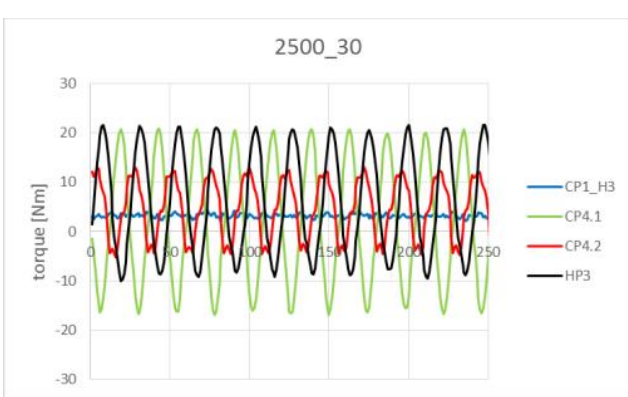

Fig. 8. Torque on the pump shaft at a pumping pressure of $30 \mathrm{MPa}$ and a pump shaft speed of $2500 \mathrm{rpm}$

The lowest torque amplitude value was registered for the CP1_H3 pump. The torque amplitude analysis ( Fig. 7) 
shows that the lowest value is obtained for the CP1 pump at both low and high pressures and at low and high speeds (minimum approx. $3 \mathrm{Nm}$, maximum approx. $28 \mathrm{Nm}$ ). A comparable maximum value was also recorded for CP4.2. The highest torque amplitude values can be observed for CP4.1 and HP3. For a pumping pressure of 30 $\mathrm{MPa}$, it is about $39 \mathrm{Nm}$, and for a pumping pressure of 140 $\mathrm{MPa}$ about $59 \mathrm{Nm}$.

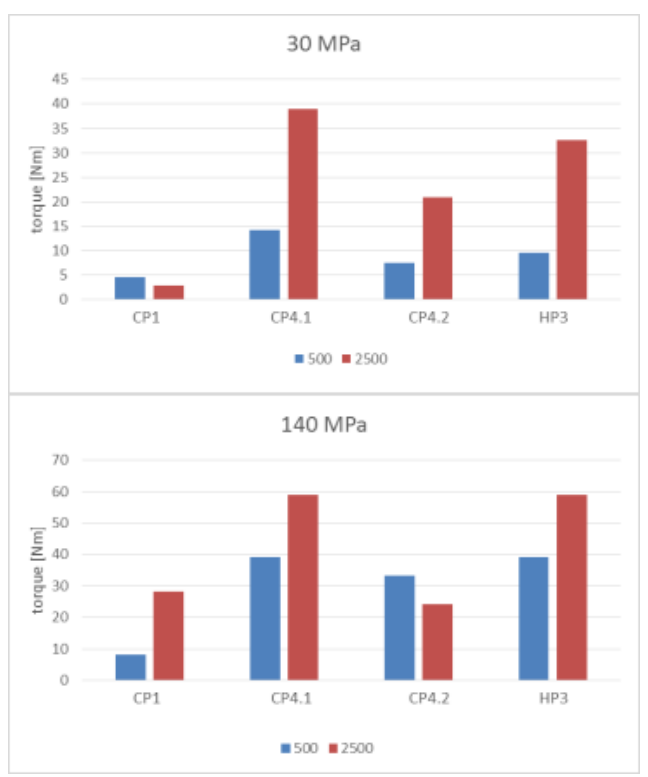

Fig. 3. Torque amplitude on the pump shaft at a pumping pressure of 30 and $140 \mathrm{MPa}$ and pump shaft speeds of 500 and $2500 \mathrm{rpm}$

Figure 10 and Fig. 11 show the minimum and maximum torque values in relation to the pumping pressure and the pump shaft speed. The most regular torque, mostly of positive or slightly negative (approx. -3 and $-7 \mathrm{Nm}$ ) values, over the entire operating range is for the CP1 and CP4.2 pumps. The second group is the CP4.1 and HP3 pumps. The torque takes both positive and negative values. The CP4.1 pump has higher negative values of approx. $-25 \mathrm{Nm}$ at high speeds. The highest positive torque of the HP3 pump (about $53 \mathrm{Nm}$ ) at $140 \mathrm{MPa}$ and $2500 \mathrm{rpm}$.

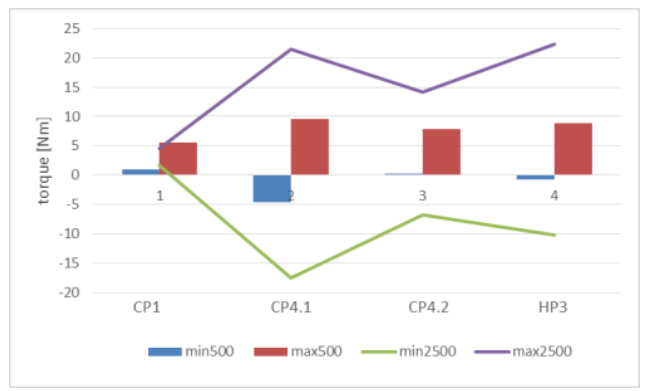

Fig. 10. Minimum and maximum torque at $30 \mathrm{MPa}$ pumping pressure and 500 and $2500 \mathrm{rpm}$ shaft speeds

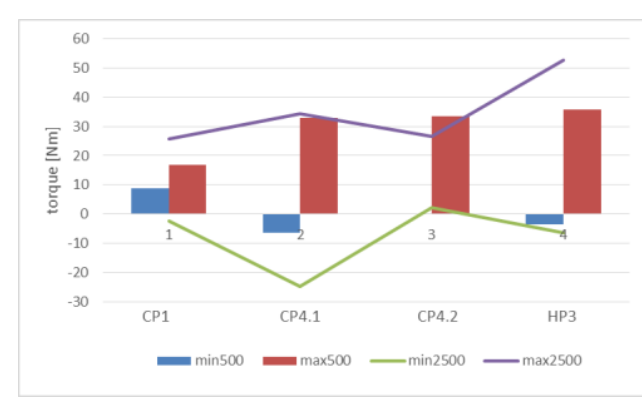

Fig.11. Minimum and maximum torque at $140 \mathrm{MPa}$ pumping pressure and 500 and $2500 \mathrm{rpm}$ shaft speeds

\section{Summary}

The tests show that to power an engine of a power of about $100 \mathrm{~kW}$ and with three injectors (one per combustion chamber), all three pumps have the required flow rate, both at idle and maximum load conditions. If six injectors (two per combustion chamber) are used, the CP4.1 pump does not provide the required capacity at maximum load.

Analyzing the specific flow rate, it can be stated that there are smaller differences between the tested pumps at the maximum pumping pressure. It is also observed that the CP4.2 pump has an almost constant the specific flow rate in the entire speed range. The efficiencies of the other pumps are highest in the range of 500-1500 rpm.

The smallest torque amplitude is recorded for the CP1 pump. There is a positive torque almost over its entire operating range, which ensures that the drive system is loaded with one-way forces. Another advantage is the number of pumping sections, allowing the synchronization of pumping and fuel injection. However, its large mass and no individual high-pressure connections disqualifies it from mounting in the aircraft engine.

The best option is the CP4.1 pump due to its small mass. However, it has one pumping section, which cannot guarantee the required safe operation of aircraft. With this in mind, a pump with a minimum of two pumping sections and pressure individually discharged into the fuel rail/rails can be applied, which makes the system more reliable. Pumps CP4.2 and HP3 satisfy these requirements. The required flow rate is achieved in the speed range of 1500 $2000 \mathrm{rpm}$. This allows the use of a 1:2 pump drive ratio in relation to the engine crankshaft, reduction of rotation and operation with the highest efficiency (specific flow rate). The pumps are flanged and can be fitted with a toothed wheel or a belt. Accordingly, a toothed or belt transmission can be used and the pump can be more flexibly mounted on the engine with other engine equipment. The advantage of HP3 is the opposite position of its pumping sections and a built-in pre-feed pump. The disadvantage of the pump is that the flow rate decrease with increasing speed (especially at $30 \mathrm{MPa}$ ) and higher torque amplitude.

\section{Acknowledgements}

This work has been realized in the cooperation with The Construction Office of WSK "PZL-KALISZ" S.A." and is part of Grant Agreement No. POIR.01.02.00-00-0002/15 financed by the Polish Nation-al Centre for Research and Development. 


\section{Bibliography}

[1] PIRAULT, J., FLINT, M. Opposed Piston Engines: Evolution, Use, and Future Applications. SAE Technical Paper. 2009.

[2] Heywood, J. Internal combustion engine fundamentals. McGraw-Hill International Editions. 1988.

[3] FRANKE, M., HUANG, H., LIU, J. Opposed piston opposed cylinder $450 \mathrm{hp}$ engine: performance development by CAE simulations and testing. SAE Technical Paper. 2006.

[4] MA, F., ZHAO, C., ZHANG, F. et al. Effects of scavenging system configuration on in-cylinder air flow organization of an opposed-piston two-stroke engine. Energies. 2015, 58665884.

[5] PETER, H. Opposed piston opposed cylinder (OPOC) engine for military ground vehicles. SAE Technical Paper. 2005-01-1548, 2005.

[6] NAIK, S., JOHNSON, D., KOSZEWNIK, J. et al. Practical applications of opposed-piston engine technology to reduce fuel consumption and emissions. SAE Technical Paper 2013-01-2754, 2013.

[7] REGNER, G., JOHNSON, D., KOSZEWNIK, J., LYNN, F. Modernizing the opposed piston, two stroke engine for clean. efficient transportation. SAE Technical Paper. 201326-0114, 2013.

[8] GHARAKHANI, A., GHONIEM, A.F. 3D vortex simulation of flow in an opposed-piston engine. Esaim Proc. 1999 , 7, 161-172.

[9] REGNER, G., HEROLD, R.E., WAHL, M.H. et al. The Achates power opposed-piston two-stroke engine: performance and emissions results in a medium-duty application. SAE Technical Paper. 2011-01-2221, 2011.

[10] STUMPP, G., RICCO, M. Common rail-an attractive fuel injection system for passenger car DI diesel engines. Proceedings of the International Congress and Exposition. Society of Automotive Engineers (SAE), 26-29 February 1996.

[11] BOEHNER, W., HUMMEL, K. Common rail injection system for commercial diesel vehicles. SAE International. 1997.

[12] REDON, F. Opposed-piston engine for light-duty applications. SAE High Efficiency IC Engine Symposium, 2013.

[13] CATANIA, A.E., FERRARI, A., MANNO, M., SPESSA, E. Experimental investigation of dynamic effects on multipleinjection common rail system performance. J. Eng. Gas Turbines Power. 2008, 130, 460-466.

[14] HENEIN, N.A., LAI, M.C., SINGH, I.P. et al. Characteristics of a common rail diesel injection system under pilot and postinjection modes. SAE Technical Paper. 2002-01-0218, 2002.

Rafał Sochaczewski, DEng. - Faculty of Mechanical Engineering, Lublin University of Technology. e-mail: r.sochaczewski@pollub.pl

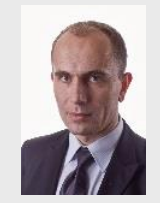

Marcin Szlachetka, DEng. - Faculty of Mechanical Engineering, Lublin University of Technology. e-mail:m.szlachetka@pollub.pl
[15] BIANCHI, G.M., FALFARI, S., PELLONI, P. et al. Numerical and experimental study towards possible improvements of common rail injectors. SAE Technical Paper. 2002-01$0500,2002$.

[16] YANG, F.Y., ZHANG, J.Y., WANG, X.G. et al. Judgement and application of ignition moment during engine startup period based on crankshaft transient acceleration analysis. $A u$ tom. Eng. 2003, 25, 111-115.

[17] SONG, G.M., YANG, F.Y., OUYANG, M.G. et al. Equilibrium algorithm research for each individual cylinders of common rail based on self-adaptive fuzzy control. Trans. Csice. 2005, 23, 451-456.

[18] SONG, J., TIAN, L.Y., LI, X.L. et al. Design of ECU for common rail system of diesel engine and study of injection characteristics. Trans. Csice. 2006, 24, 28-34.

[19] BIANCHI, G., PELLONI, P., CORCIONE, F., LUPPINO F. Numerical analysis of passenger car HSDI diesel engines with the 2nd generation of common rail injection systems: the effect of multiple injections on emissions. SAE Technical Paper. 2001.

[20] CATAlano, L., TONDOlO, V., DADONE, A. Dynamic rise of pressure in the common-rail fuel injection system. SAE Technical Paper. 2002.

[21] KLYZA, C.A. Fuel injection strategies in opposed-piston engines with multiple fuel injectors, Pub. No.: US 2017/0198632 A1, San Diego 2017.

[22] SOCHACZEWSKI, R., SZLACHETKA, M. Numerical analysis of a fuel pump for an aircraft diesel engine. MATEC Web of Conferences. 2019, 252, 01003.

[23] SOCHACZEWSKI, R., CZYŻ, Z., SIADKOWSKA, K. Modeling a fuel injector for a two-stroke diesel engine. Combustion Engines. 2017, 170(3), 147-154.

[24] NAIK, S. et al. Practical applications of opposed-piston engine technology to reduce fuel consumption and emissions. SAE Technical Paper. 2013-01-2754. 2013. DOI: 10.4271/2013-01-2754

[25] GRABOWSKI, Ł., PIETRYKOWSKI, K., KARPIŃSKI P. Charging process analysis of an opposed-piston two-stroke aircraft Diesel engine. Web of Science. ITM Web of Conferences. 2017, 15.

[26] http://www.ni.com/pl

[27] https://www.zemiceurope.com

[28] Autoelektronika 2017, Opis Techniczny Stanowiska Testowania Pomp i Wtryskiwaczy STPiW3.

[29] https://meister-flow.de
Prof. Mirosław Wendeker, DSc., DEng. - Faculty of Mechanical Engineering, Lublin University of Technology.

e-mail:m.wendeker@pollub.pl

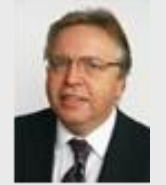

Paweł Karpiński, MEng. - Faculty of Mechanical Engineering, Lublin University of Technology. e-mail:pawel.karpinski@pollub.edu.pl 